\title{
Genetic parameters of calcium, phosphorus, magnesium, and potassium serum concentrations during the first 8 days after calving in Holstein cows
}

\author{
V. Tsiamadis, ${ }^{*}$ G. Banos, ${ }^{*} \dagger$ N. Panousis, $\ddagger$ M. Kritsepi-Konstantinou, $\S$ G. Arsenos, ${ }^{*}$ and G. E. Valergakis ${ }^{* 1}$ \\ *Department of Animal Production, Faculty of Veterinary Medicine, Box 393, Aristotle University of Thessaloniki, GR-54124 Thessaloniki, Greece \\ †Scotland's Rural College, Roslin Institute, Edinburgh, United Kingdom EH25 9RG \\ $\ddagger$ Clinic of Farm Animals, and \\ §Diagnostic Laboratory, Department of Clinics, Faculty of Veterinary Medicine, Aristotle University of Thessaloniki, GR-54124 Thessaloniki, \\ Greece
}

\section{ABSTRACT}

Calcium, $\mathrm{Mg}, \mathrm{P}$, and $\mathrm{K}$ are of great importance for the health and productivity of dairy cows after calving. So far genetic studies have focused on clinical hypocalcemia, leaving the genetic parameters of these macroelements unstudied. Our objective was to estimate the genetic parameters of $\mathrm{Ca}, \mathrm{Mg}, \mathrm{P}$, and $\mathrm{K}$ serum concentrations and their changes during the first $8 \mathrm{~d}$ after calving. The study was conducted in 9 herds located in northern Greece, with 1,021 Holstein cows enrolled from November 2010 until November 2012. No herd used any kind of preventive measures for hypocalcemia. Pedigree information for all cows was available. A total of 35 cows were diagnosed and treated for periparturient paresis and, therefore, excluded from the study. The remaining 986 cows were included in genetic analysis. The distribution of cows across parities was 459 (parity 1), 234 (parity 2), 158 (parity 3), and 135 (parity $\geq 4$ ). A sample of blood was taken from each cow on $d$, 2,4 , and 8 after calving and serum concentrations of $\mathrm{Ca}, \mathrm{P}, \mathrm{Mg}$, and $\mathrm{K}$ were measured in each sample. A final data set of 15,390 biochemical records was created consisting of 3,903 Ca, 3,902 P, 3,903 Mg, and 3,682 $\mathrm{K}$ measurements. Moreover, changes of these concentrations between $\mathrm{d} 1$ and 4 as well as 1 and 8 after calving were calculated and treated as different traits. Random regression models were used to analyze the data. Results showed that daily heritabilities of $\mathrm{Ca}, \mathrm{P}$, and $\mathrm{Mg}$ concentrations traits were moderate to high $(0.20-0.43)$, whereas those of $\mathrm{K}$ were low to moderate (0.12-0.23). Regarding concentration changes, only $\mathrm{Mg}$ change between $\mathrm{d} 1$ and 8 after calving had a significant heritability of 0.18 . Genetic correlations between Ca, $\mathrm{P}, \mathrm{Mg}$, and $\mathrm{K}$ concentrations and their concentration

Received December 21, 2015.

Accepted March 18, 2016.

${ }^{1}$ Corresponding author: geval@vet.auth.gr changes from d 1 to 4 and 1 to 8 after calving were not significantly different from zero. Most phenotypic correlations among $\mathrm{Ca}, \mathrm{P}, \mathrm{Mg}$, and $\mathrm{K}$ concentrations were positive and low (0.09-0.16), whereas the correlation between $\mathrm{P}$ and $\mathrm{Mg}$ was negative and low $(-0.16)$. Phenotypic correlations among macromineral concentrations on $\mathrm{d} 1$ and their changes from $\mathrm{d} 1$ to 4 and 1 to 8 after calving varied for each macromineral. This study revealed that genetic selection for normal Ca, P, $\mathrm{Mg}$, and $\mathrm{K}$ concentrations in the first week of lactation is possible and could facilitate the management of their deficiencies during the early stages of lactation.

Key words: macrominerals, genetic parameters

\section{INTRODUCTION}

During the first critical days after calving, Ca, P, $\mathrm{Mg}$, and $\mathrm{K}$ blood serum concentrations are of great importance for the health and productivity of the dairy cow. Possible deviations from normal levels of these macrominerals are interrelated (Goff and Horst, 1997; Goff, 2000; Lean et al., 2013).

Calcium plays a key role at the onset of lactation (DeGaris and Lean, 2008). Hypocalcaemia (serum Ca $<8.3 \mathrm{mg} / \mathrm{dL}$ ) is the most important macromineral disorder of the transition dairy cow (Oetzel, 2011; Goff, 2014; Martinez et al., 2014). It is associated with health disorders including retained fetal membranes, mastitis, uterine infection, displaced abomasum, and ketosis (Correa et al., 1990; Gröhn and Bruss, 1990; DeGaris and Lean, 2008), as well as reduced dry matter intake and milk production (Rajala-Schultz et al., 1999).

Phosphorus and Mg play important roles in the etiology of hypocalcemia, as well. Hypophosphatemia (serum $\mathrm{P}<4.0 \mathrm{mg} / \mathrm{dL}$ ) is involved in the manifestation of the alert downer cow syndrome, whereas elevated phosphorus concentrations increase the risk of milk fever (Lean et al., 2013; Grünberg, 2014). Hypomagnesemia (serum $\mathrm{Mg}<1.8 \mathrm{mg} / \mathrm{dL}$ ) reduces parathyroid hormone (PTH) secretion, tissue sensitivity to PTH, and syn- 
thesis of 1,25-dihydroxycholecalciferol (Littledike et al., 1983; Rude, 1998). Moreover, mild hypomagnesemia (serum $\mathrm{Mg}$ between 1.3 and $1.8 \mathrm{mg} / \mathrm{dL}$ ) is common in anorectic fresh cows and in most cases is accompanied by mild hypophosphatemia (serum $\mathrm{P}$ between 2 and 4 $\mathrm{mg} / \mathrm{dL}$ ) and mild hypokalemia (serum $\mathrm{K}$ between 2.6 and $3.9 \mathrm{mmol} / \mathrm{L}$; Peek and Divers, 2008).

Potassium homeostasis in transition dairy cows is affected by numerous factors. Off-feed fresh cows, increased milk production, and concurrent diseases predispose to hypokalemia (serum $\mathrm{K}<3.9 \mathrm{mmol} / \mathrm{L}$; Pradhan and Hemken, 1968; Sattler et al., 1998; Sattler and Fecteau, 2014).

Blood $\mathrm{Ca}$ concentration is considered to reach its minimum 12 to $24 \mathrm{~h}$ after calving and then increase gradually (Goff, 2014). Relative estimates for the other 3 macrominerals are lacking from the literature.

Serum $\mathrm{Ca}, \mathrm{P}, \mathrm{Mg}$, and $\mathrm{K}$ concentrations are influenced by environmental factors, mainly nutrition (NRC, 2001; Kronqvist, 2011). Nutritional and management strategies for the prevention of these macromineral deficiencies have been developed (Bethard et al., 1998; Tauriainen et al., 2003; Rérat et al., 2009); however, a genetic component to these traits also exists, as reported for serum Ca concentration by Tveit et al. (1991).

Genetic studies so far have focused on heritability estimates of clinical hypocalcemia (milk fever) (Dyrendahl et al., 1972; Lin et al., 1989; Abdel-Azim et al., 2005) and genetic and phenotypic correlations between milk fever and various disease (Lin et al., 1989) and production traits (Lyons et al., 1991; Uribe et al., 1995; Heringstad et al., 2005). Tveit et al. (1991) reported heritability estimates for postpartum serum Ca concentrations in first-lactation Norwegian cows. However, genetic studies of serum $\mathrm{Ca}, \mathrm{P}, \mathrm{Mg}$, and $\mathrm{K}$ concentrations in fresh Holstein dairy cows are lacking. Therefore, the objective of our study was to estimate the genetic parameters of $\mathrm{Ca}, \mathrm{Mg}, \mathrm{P}$, and $\mathrm{K}$ serum concentrations and their changes in Holstein cows during the first $8 \mathrm{~d}$ after calving.

\section{MATERIALS AND METHODS}

The research was conducted in compliance with institutional guidelines and approved by the Research Committee of the Aristotle University of Thessaloniki, Thessaloniki, Greece. All farmers gave informed consent for the cows to be included in the study and the testing procedures.

\section{Animals and Management}

A total of 1,021 Holstein cows from 9 commercial freestall dairy herds in northern Greece were included in the study. The distribution across parities was 466 , 242,165 , and 148 cows for parities $1,2,3$, and $\geq 4$, respectively. Farms were visited regularly between November 2010 and November 2012 for data collection. No herd used any kind of preventive measures for hypocalcemia. Total mixed rations were formulated to meet or exceed net energy and MP requirements according to NRC (2001) recommendations.

\section{Clinical Examination, Blood Sampling, and Analyses}

Each animal was clinically examined and blood sampled on d 1, 2, 4, and 8 after calving, by the first author. Blood samples, in all herds, were collected between 0800 and $1000 \mathrm{~h}$, after the morning milking. Moreover, to standardize sampling and handling procedures, all samplings were performed in absence of unusual stressors and in proper containment systems that minimize stress and pain of the animal.

Blood sampling was performed by coccygeal venipuncture into $10-\mathrm{mL}$ vacuum glass tubes without anticoagulant (BD Vacutainer, Plymouth, UK) for serum macromineral measurements. Samples were placed in a cooler, transported to the Diagnostic Laboratory of the Faculty of Veterinary Medicine, and centrifuged immediately upon arrival $[3,000 \times g$ for $15 \mathrm{~min}$ at room temperature $\left.\left(21^{\circ} \mathrm{C}\right)\right]$. Serum was transferred into polyethylene tubes and stored at $-80^{\circ} \mathrm{C}$ until assay. All sera were analyzed for total $\mathrm{Ca}$ and $\mathrm{Mg}$ concentrations using flame atomic absorption spectrophotometry (Perkin ElmerAAnalyst 100, Perkin Elmer Co, Norwalk, CT) according to the manufacturer's instructions. Serum inorganic phosphorus concentrations were determined photometrically using a Flexor E autoanalyzer (Vital Scientific, Spankeren, the Netherlands), according to the procedure described by Daly and Ertingshausen (1972), with the use of standard commercial reagents (Thermo Fisher Scientific, Waltham, MA). Potassium serum concentrations were measured using an ion-selective electrode according to manufacturer's instructions (Electrolyte Analyzer 9180, Roche, Basel, Switzerland). The intra- and interassay coefficients of variation for all the above analyses were less than $3 \%$.

\section{Dataset}

Considering that pedigree information was available for all cows, the total population increased to 4,262 animals, spanning the last 5 generations. Calving date, parity number, calving ease, and twinning was recorded.

A total of 35 cows were diagnosed with periparturient paresis, treated appropriately with intravenous $\mathrm{Ca}$, and excluded from the study. Therefore, the remaining 986 cows were finally included in the genetic analysis. The 
distribution across parities was 459, 234, 158, and 135 cows for parities $1,2,3$, and $\geq 4$, respectively.

Following all analyses, a dataset of 15,390 biochemical records was created (Table 1), consisting of 3,903 $\mathrm{Ca}, 3,902 \mathrm{P}, 3,903 \mathrm{Mg}$, and 3,682 K serum concentration measurements. Moreover, changes of these concentrations between d 1 and 4 as well as d 1 and 8 were calculated and treated as different traits.

\section{Statistical Analysis}

Repeated cow records of $\mathrm{Ca}, \mathrm{Mg}, \mathrm{P}$, and $\mathrm{K}$ serum concentrations were analyzed with a random regression model which accounted for the covariance between successive records of the same animal; each trait was analyzed separately:

$$
\begin{aligned}
& Y_{i j k m}=H Y S_{i}+L_{j}+M_{k}+a_{1} \cdot \text { age }+ \\
& \sum_{n=0}^{2} b_{m} P_{m} D_{m}+\sum_{n=0}^{2} A_{k m} P_{m} D_{m}+e_{i j k m},
\end{aligned}
$$

where $Y_{i j k m}$ is the macromineral concentration of cow $k$ on day from calving $m ; H Y S_{i}$ is the fixed effect of herd-year-season of calving $i$ (72 levels); $L_{j}$ the fixed effect of number of lactation (4 levels); $M_{k}$ the fixed effect of calendar month when the record was taken $k$ (12 levels); $a_{1}$ the linear regression coefficient on age at calving (age); $D_{m}$ the number of days from calving; $b_{m}$ the fixed regression coefficient on days from calving; $A_{k m}$ the random regression coefficient on day from calving associated with the additive genetic effect of cow $k$ including all pedigree data (4,262 animals); $P_{m}$ the $m$ th orthogonal polynomial of day from calving $(m$ the order of polynomial); and $e_{i j k m}$ the random residual term.

The fixed effects in the model were fitted after preliminary analyses had confirmed their statistically significant effect $(P<0.05)$ on the traits. The final order of the random polynomial (third for either trait) was determined with the use of the log-likelihood test in sequential analyses of gradually increasing orders. The final order choice was also confirmed with the Akaike information criterion test. Four measurement error classes were defined using the time relative to calving as $\mathrm{d} 1,2,4$, and 8. The definition of these classes, even at this small time span, aimed to capture the dayto-day differences in health events at the beginning of lactation. Covariances between the error classes were assumed to be zero.

Estimates of variance components from model 1 were used to calculate heritabilities for each trait and day after calving. Variance components and heritability estimated for $\mathrm{Ca}, \mathrm{K}, \mathrm{P}$, and $\mathrm{Mg}$ serum concentrations

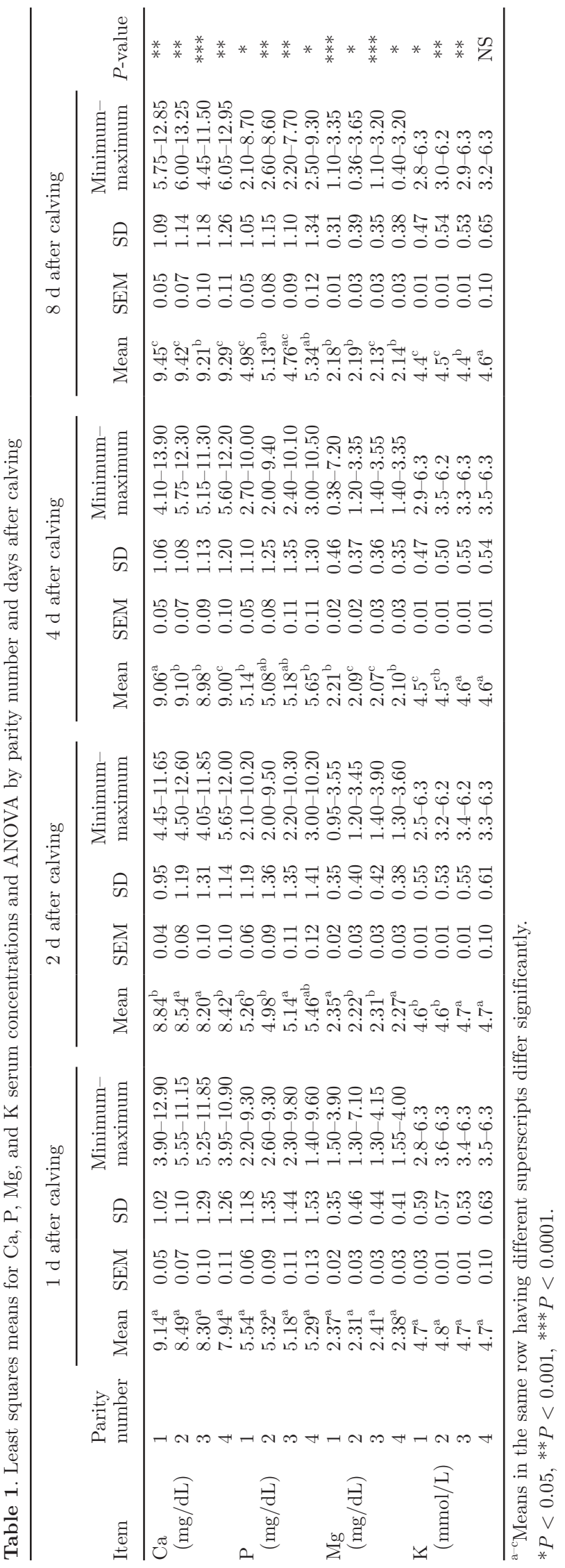

Journal of Dairy Science Vol. 99 No. 7, 2016 
were also calculated across all days from calving using the following model:

$$
Y_{i j k m}=H Y S_{i}+L_{j}+a_{1} \cdot \operatorname{age}+D_{m}+A_{k}+e_{i j k m},[2]
$$

where $Y_{i j k m}$ is the macromineral concentration change of cow $k ; A_{k}$ is the additive genetic effect of cow $k$ and all effects are as in equation 1.

Serum concentration changes between d 1 and 4 as well as d 1 and 8 after calving were analyzed with the following model:

$$
Y_{i j k}=H Y S_{i}+L_{j}+\text { age }+A_{k}+e_{i j k},
$$

where $Y_{i j k}$ is the macromineral concentration change of cow $k$ and all other effects are as in equation 2 .

Genetic and phenotypic correlations among all traits analyzed with the above models were estimated with a series of bivariate analyses. All analyses were conducted using the statistical software package ASREML (Gilmour et al., 2006).

\section{RESULTS}

\section{Mean Macromineral Serum Concentrations and Prediction Lines for Concentrations}

Mean serum $\mathrm{Ca}$ concentration increased gradually from d 1 to 8 after calving $(P<0.001)$. In first- and second-lactation cows, mean $\mathrm{Ca}$ concentration remained above the $8.3-\mathrm{mg} / \mathrm{dL}$ threshold throughout the sampling period, whereas in older cows it was below the threshold on d 1 and 2 after calving. On the contrary, mean serum $\mathrm{P}, \mathrm{Mg}$, and $\mathrm{K}$ concentrations decreased from d 1 to 8 after calving $(P<0.001)$. Descriptive statistics and ANOVA results by parity are presented in Table 1. Fixed curves of serum macromineral concentrations across all lactations during the first $8 \mathrm{~d}$ after calving from the random regression model analysis (equation 1) are shown in Figure 1. These curves are adjusted for all other effects included in equation 1 .

\section{Serum Macromineral Concentrations Variances and Heritabilities Estimates}

Estimates of day-to-day phenotypic, genetic, and residual variances, and heritabilities for serum $\mathrm{Ca}, \mathrm{P}, \mathrm{Mg}$, and $\mathrm{K}$ concentrations are presented in Table 2. All estimates were statistically greater than zero $(P<0.001)$. During the first $8 \mathrm{~d}$ after calving the estimated phenotypic $\left(\sigma_{p}^{2}\right)$ and residual variances $\left(\sigma_{r}^{2}\right)$ for $\mathrm{Ca}$ and $\mathrm{P}$ serum concentrations were high, whereas those of $\mathrm{Mg}$ and $\mathrm{K}$ were low. During the same period, the estimated ge- netic variance $\left(\sigma_{a}^{2}\right)$ for $\mathrm{Ca}$ and $\mathrm{P}$ serum concentration was moderate and high, respectively, whereas for $\mathrm{Mg}$ and $\mathrm{K}$ it was low. Day-to-day heritabilities of serum Ca, $\mathrm{P}$, and $\mathrm{Mg}$ concentrations were moderate $\left(\mathrm{h}^{2}=0.20\right.$ $0.43)$, whereas heritability estimates of $\mathrm{K}$ serum concentrations were low $\left(\mathrm{h}^{2}=0.12-0.15\right)$ except on $\mathrm{d} 8$ after calving $\left(h^{2}=0.23\right.$; Figure 2$)$.

Heritability estimates of serum $\mathrm{Ca}, \mathrm{P}, \mathrm{Mg}$, and $\mathrm{K}$ concentrations across all days using equation 2 are in Table 3. Although smaller, they were comparable with the ones derived with the random regression model analysis. Regarding concentration changes, only $\mathrm{Mg}$ change between d 1 and 8 after calving had a significant $(P<0.05)$ heritability of 0.18 .

\section{Serum Macromineral Concentrations Correlations}

Significant genetic correlations between serum Ca, $\mathrm{P}, \mathrm{Mg}$, and $\mathrm{K}$ concentrations and their concentration changes from d 1 to 4 and 1 to 8 after calving were not detected in the present study. Statistically significant $(P<0.010-0.001)$ phenotypic correlations among Ca, $\mathrm{P}, \mathrm{Mg}$, and $\mathrm{K}$ serum concentrations are shown in Table 3. Most correlations were positive and low (phenotypic correlation, $\mathrm{r}_{\mathrm{p}}=0.09-0.16$ ), whereas the P-Mg correlation was negative and low $\left(r_{p}=-0.16 \pm 0.03 ; \pm S E\right)$.

Significant phenotypic correlations among serum macromineral concentrations on $\mathrm{d} 1$ and their changes from d 1 to 4 and 1 to 8 after calving are shown in Table 4. On d 1, a low positive correlation was observed between $\mathrm{Ca}$ and $\mathrm{P}, \mathrm{Ca}$ and $\mathrm{K}$, as well as $\mathrm{P}$ and $\mathrm{K}$; a low negative correlation was also noted between $\mathrm{P}$ and Mg. Calcium and Mg serum concentrations on d 1 had moderate negative correlations with both their changes from $\mathrm{d} 1$ to 4 and 1 to 8 . Phosphorus serum concentration on $\mathrm{d} 1$ had moderate negative correlation with its change from d 1 to 8 , whereas $\mathrm{K}$ serum concentration at $\mathrm{d} 1$ had a moderate positive correlation with its change from d 1 to 8 . Phosphorus serum concentration on $\mathrm{d} 1$ had a low positive correlation with both $\mathrm{Mg}$ changes (d 1-4 and 1-8) and a low negative one with both $\mathrm{K}$ changes (d 1-4 and 1-8). Phosphorus change from d 1 to 4 had a low negative correlation with both $\mathrm{Mg}$ changes. Both $\mathrm{P}$ changes (d 1-4 and 1-8) had a low positive correlation with both $\mathrm{K}$ changes (d 1-4 and 1-8). For each macromineral, its serum concentration changes between $\mathrm{d} 1$ to 4 and 1 to 8 were positively and moderately correlated.

\section{DISCUSSION}

The present study was designed to estimate the genetic parameters of serum $\mathrm{Ca}, \mathrm{P}, \mathrm{Mg}$, and $\mathrm{K}$ concentra- 

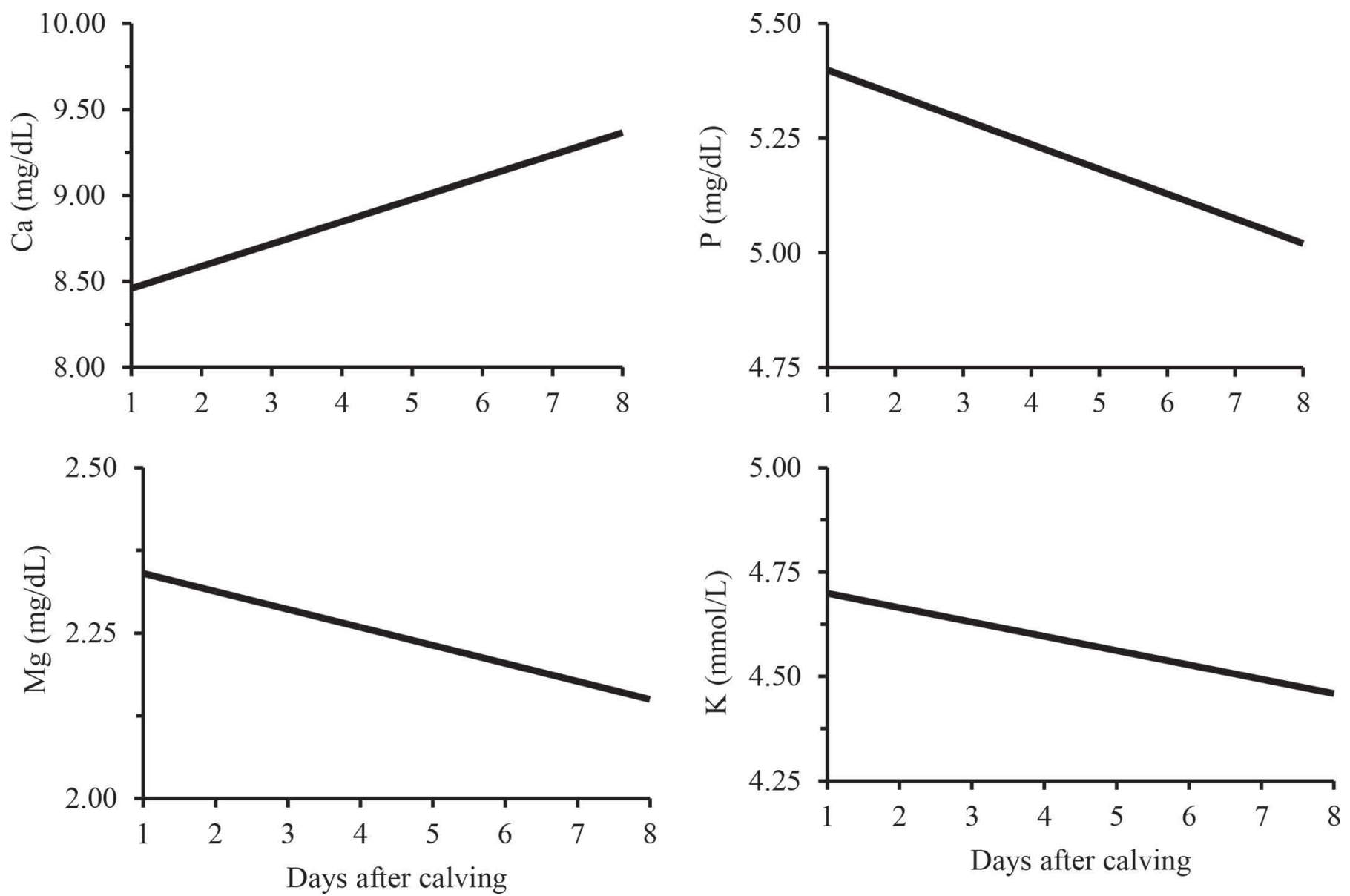

Figure 1. Fixed curves for serum $\mathrm{Ca}, \mathrm{P}, \mathrm{Mg}$, and $\mathrm{K}$ concentrations across all lactations during the first $8 \mathrm{~d}$ after calving from random regression model analyses.

Table 2. Variances and heritability estimates of $\mathrm{Ca}, \mathrm{P}, \mathrm{Mg}$, and $\mathrm{K}$ serum concentrations by days after calving from random regression model analyses ${ }^{1}$

\begin{tabular}{|c|c|c|c|c|c|}
\hline Trait & $\begin{array}{l}\text { Day after } \\
\text { calving }\end{array}$ & $\sigma_{p}^{2}$ & $\sigma_{a}^{2}$ & $\sigma_{r}^{2}$ & $\mathrm{~h}^{2}$ \\
\hline \multirow[t]{4}{*}{$\mathrm{Ca}$} & 1 & $1.40(0.06)$ & $0.44(0.05)$ & $0.96(0.06)$ & $0.32(0.03)$ \\
\hline & 2 & $1.26(0.05)$ & $0.37(0.04)$ & $0.89(0.05)$ & $0.29(0.03)$ \\
\hline & 4 & $1.22(0.05)$ & $0.28(0.03)$ & $0.94(0.05)$ & $0.23(0.02)$ \\
\hline & 8 & $1.30(0.06)$ & $0.35(0.08)$ & $0.95(0.08)$ & $0.27(0.06)$ \\
\hline \multirow[t]{4}{*}{$\mathrm{P}$} & 1 & $1.91(0.08)$ & $0.70(0.07)$ & $1.21(0.07)$ & $0.37(0.03)$ \\
\hline & 2 & $1.48(0.06)$ & $0.57(0.05)$ & $0.92(0.05)$ & $0.38(0.03)$ \\
\hline & 4 & $1.31(0.06)$ & $0.40(0.03)$ & $0.91(0.05)$ & $0.30(0.02)$ \\
\hline & 8 & $1.05(0.05)$ & $0.45(0.08)$ & $0.60(0.07)$ & $0.43(0.07)$ \\
\hline \multirow[t]{4}{*}{$\mathrm{Mg}$} & 1 & $0.17(0.01)$ & $0.07(0.01)$ & $0.11(0.01)$ & $0.39(0.03)$ \\
\hline & 2 & $0.16(0.01)$ & $0.06(0.01)$ & $0.10(0.01)$ & $0.35(0.03)$ \\
\hline & 4 & $0.19(0.01)$ & $0.04(0.00)$ & $0.15(0.01)$ & $0.20(0.02)$ \\
\hline & 8 & $0.12(0.01)$ & $0.03(0.01)$ & $0.10(0.01)$ & $0.21(0.06)$ \\
\hline \multirow[t]{4}{*}{$\mathrm{K}$} & 1 & $0.34(0.02)$ & $0.04(0.01)$ & $0.30(0.02)$ & $0.12(0.03)$ \\
\hline & 2 & $0.29(0.01)$ & $0.04(0.01)$ & $0.26(0.01)$ & $0.12(0.02)$ \\
\hline & 4 & $0.21(0.01)$ & $0.03(0.01)$ & $0.18(0.01)$ & $0.15(0.02)$ \\
\hline & 8 & $0.22(0.01)$ & $0.05(0.01)$ & $0.17(0.01)$ & $0.23(0.06)$ \\
\hline
\end{tabular}

\footnotetext{
${ }^{1}$ All estimates were statistically greater than zero at $P<0.001$ level. Phenotypic $\left(\sigma_{p}^{2}\right)$, genetic $\left(\sigma_{a}^{2}\right)$, residual
} variances $\left(\sigma_{r}^{2}\right)$, and heritability $\left(\mathrm{h}^{2}\right)$ estimates (SE in parentheses). 


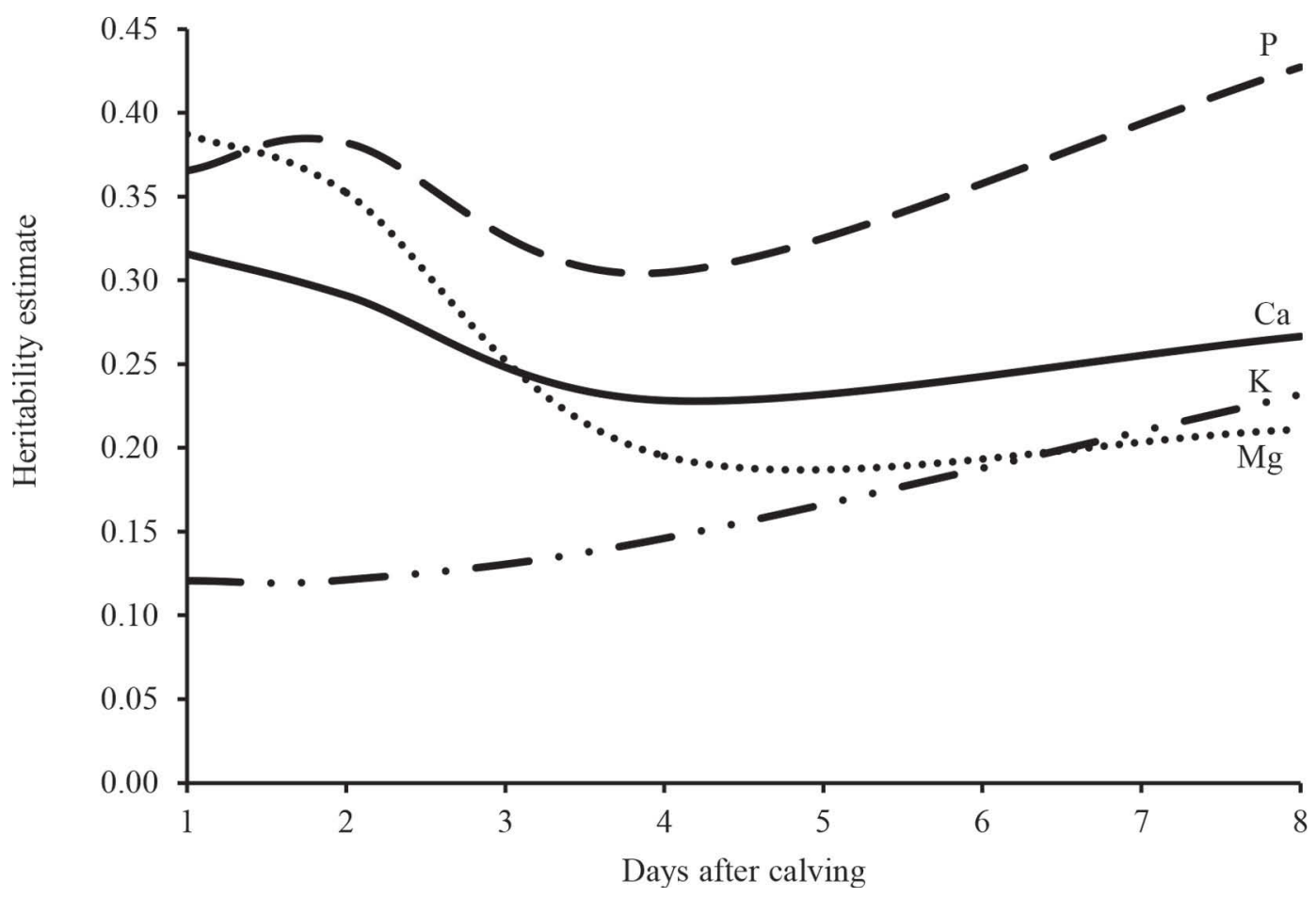

Figure 2. Heritability estimates of serum $\mathrm{Ca}, \mathrm{P}, \mathrm{Mg}$, and $\mathrm{K}$ concentrations during the first $8 \mathrm{~d}$ after calving.

tions immediately after calving. Normally, serum Ca concentration is maintained within a narrow range, between 8.3 and $10.4 \mathrm{mg} / \mathrm{dL}$ (Goff, 2014). During the first 12 to $24 \mathrm{~h}$ after calving, Ca concentration reaches the lower value and then gradually increases (Goff, 2014). In the present study, an increase across all lactations in serum Ca concentrations from d 1 to 8 after calving was observed. Mean Ca serum concentrations from d 1 to 8 were different, depending on parity number and days after calving. Response of cows to the decreased serum $\mathrm{Ca}$ concentration was not similar across lactations. The homeorhetic mechanisms that determine the $\mathrm{Ca}$ balance (parathyroid hormone, cholecalciferol, and calcitonin) restored $\mathrm{Ca}$ serum concentration in most first- and second-parity cows. However, in older cows ( 3 and $\geq 4$ parities) the same homeorhetic mechanisms that affect the $\mathrm{Ca}$ concentration did not react as efficiently, put- ting these animals in a profound hypocalcemic status just after calving (d 1).

The prediction curve generated with the random regression model denotes a significant rise in $\mathrm{Ca}$ concentration from d 1 to 8 across all lactations. This is in agreement with results from studies dealing with Ca physiology after calving (Littledike and Goff, 1987; Goff, 2000; DeGaris and Lean, 2008). Furthermore, mean serum $\mathrm{P}, \mathrm{Mg}$, and $\mathrm{K}$ concentrations were within reference ranges $(\mathrm{P}=4.2-7.7 \mathrm{mg} / \mathrm{dL} ; \mathrm{Mg}=1.8-2.4$ $\mathrm{mg} / \mathrm{dL} ; \mathrm{K}=3.9-5.8 \mathrm{mmol} / \mathrm{L} ;$ Goff, 2008; Peek and Divers, 2008) during the first day after calving and then gradually decreased, but always remaining within those ranges. The prediction curves denote a significant decline in $\mathrm{P}, \mathrm{Mg}$, and $\mathrm{K}$ concentrations from $\mathrm{d} 1$ to 8 across all lactations. Serum $\mathrm{Ca}$ and $\mathrm{P}$ concentrations are regulated by the same hormones; the main

Table 3. Heritability estimates of $\mathrm{Ca}, \mathrm{P}, \mathrm{Mg}$, and $\mathrm{K}$ serum concentrations across days (diagonals) and statistically greater than zero phenotypic correlations (above diagonal); SE in parentheses ${ }^{1}$

\begin{tabular}{lcccc}
\hline Trait & $\mathrm{Ca}$ & $\mathrm{P}$ & $\mathrm{Mg}$ & $\mathrm{K}$ \\
\hline $\mathrm{Ca}$ & $0.20(0.02)^{* *}$ & $0.16(0.03)^{* *}$ & $\mathrm{NS}$ & $0.09(0.03)^{*}$ \\
$\mathrm{P}$ & & $0.25(0.02)^{* *}$ & $-\mathbf{0 . 1 6}(\mathbf{0 . 0 3})^{* *}$ & $0.20(0.03)^{* *}$ \\
$\mathrm{Mg}$ & & & $0.21(0.02)^{* *}$ & $\mathrm{NS}$ \\
$\mathrm{K}$ & & & $0.10(0.02)^{* *}$ \\
\hline
\end{tabular}

${ }^{1}$ Bold font indicates undesirable correlations.

${ }^{*} P<0.01,{ }^{* *} P<0.0001$. 
regulatory hormone is $\mathrm{PTH}$, which increases $\mathrm{Ca}$ and decreases $\mathrm{P}$ concentration within normal ranges. The increase in PTH mobilization due to decreased Ca levels can explain the concurrent fall in $\mathrm{P}$ concentration observed in the present study. Regarding $\mathrm{Mg}$ and $\mathrm{K}$, as no major hormonal control exists for these macrominerals (Kaneko et al., 2008), the observed decrease in their concentrations is difficult to explain but may be attributed to the demands of the increasing milk production.

Large-scale field studies on $\mathrm{Ca}, \mathrm{P}$, and $\mathrm{Mg}$ and $\mathrm{K}$ serum concentrations during the first week after calving are lacking in literature. Recently, Reinhardt et al. (2011) conducted a field study for hypocalcemia in 1,462 cows, with only $1 \mathrm{Ca}$ measurement within $48 \mathrm{~h}$ postpartum. To our knowledge this is the first time that repeated measurements of $\mathrm{Ca}, \mathrm{P}, \mathrm{Mg}$, and $\mathrm{K}$ concentrations during the first $8 \mathrm{~d}$ after calving are reported. The observed variation allowed the development of $\mathrm{Ca}, \mathrm{P}$, $\mathrm{Mg}$, and $\mathrm{K}$ serum concentration prediction lines with the use of random regression model.

The estimated day-to-day heritabilities for serum $\mathrm{Ca}$ concentration were moderate $(0.23-0.32)$. So far genetic studies have focused on the estimation of clinical hypocalcemia (milk fever) heritability. Some studies reported moderate to high estimates $(0.30-0.47$; Lin et al., 1989; Lyons et al., 1991, Abdel-Azim et al., 2005), whereas others (Dyrendahl et al., 1972; Pryce et al., 1997; Van Dorp et al., 1998; Heringstad et al., 2005) reported low ones (0.04-0.13) depending on lactation number, method of statistical analysis, and method of data collection, with higher estimates being observed in later lactations. Heritability estimates for serum Ca concentration in Holsteins after calving are lacking. Only one study investigated the genetic variation of $\mathrm{Ca}$ concentration in Norwegian Reds cows and reported a low heritability $(0.11 \pm 0.09)$ that was not statistically different from zero (Tveit et al., 1991).

Similarly, the estimated day-to-day heritabilities for serum $\mathrm{P}$ and $\mathrm{Mg}$ concentrations in the present study were moderate to high $(0.30-0.43$ and $0.20-0.39$, respectively), whereas those for $\mathrm{K}$ were low to moderate $(0.12-0.23)$. To our knowledge this is the first time that such estimates have been reported. So far, only Kadarmideen et al. (2000) reported heritability estimates $(0.004 \pm 0.004)$ for clinical hypomagnesemia in dairy cattle, which was not statistically different than zero. Moreover, the information for hypomagnesemia cases in their study was based on subjective clinical observations made by farmers and was not confirmed by serum $\mathrm{Mg}$ concentration measurements.

Genetic variance estimates of $\mathrm{Ca}$ and $\mathrm{P}$ were high (0.28-0.44 and 0.40-0.70, respectively), indicating high influence of additive genetic effects on these traits. Their serum concentrations are regulated mainly by 
PTH, 1,25-dihydroxyvitamin D and calcitonin (Kaneko et al., 2008). The existence of a major hormonal mechanism that regulates $\mathrm{Ca}$ and $\mathrm{P}$ concentrations can help explain the moderate to high heritability estimates of these 2 elements. It was an early belief that milk fever resulted from the failure of parathyroid glands to respond to the reduced $\mathrm{Ca}$ concentration soon after calving. However, it has been shown that such cows have very high blood PTH concentrations. Therefore, this finding implies that PTH target tissues cannot respond to its action (Goff, 2014); the main target of $\mathrm{PTH}$ is the skeleton. In humans the receptor activator of NF- $\kappa B$, receptor activator of NF- $\kappa B$ ligand, and osteoprotegerin (RANK/RANKL/OPG) system is well known for its osteoclastic function. This axis has a genetic control and is hormonally stimulated by PTH and calcitonin, both of which control serum $\mathrm{Ca}$ and $\mathrm{P}$ concentrations (Asagiri and Takayanagi, 2007; Cappariello et al., 2014). Further investigation is needed to clarify whether this axis is also functional to dairy cows and whether is involved in the etiology of hypocalcemia at the genetic level.

Genetic variance estimates for $\mathrm{Mg}$ and $\mathrm{K}$ were low (0.03-0.07 and 0.03-0.05, respectively). In humans, PTH contributes toward a small increase of $\mathrm{Mg}$ concentration (Swaminathan, 2003). Moreover, aldosterone is the only known hormone that partly regulates $\mathrm{K}$ concentration. The absence of any major hormonal mechanism that regulates the serum concentration of $\mathrm{Mg}$ and $\mathrm{K}$ may help explain the low genetic variances. The high precision of the diagnostic methods for $\mathrm{Mg}$ and $\mathrm{K}$ measurements strongly contributed to our heritability estimates.

Our results indicate that genetic improvement is possible for these traits, probably to the same degree with traits such as milk yield $\left(\mathrm{h}^{2}=0.20-0.50\right.$; CastilloJuarez et al., 2000; Windig et al., 2006; Bastin et al., $2011)$ or BCS $\left(\mathrm{h}^{2}=0.34-0.79\right.$; Berry et al., 2003; Banos et al., 2005; Oikonomou et al., 2008), which are already included in breeding programs worldwide. Both the amount of genetic variance and size of heritability for macromineral concentrations suggest that selection could be effective during the first critical days after calving. Especially for $\mathrm{Ca}$, whose role in health status and disease development is of great importance (Goff and Horst, 1997), this genetic improvement could favor animal welfare and productivity. In the meantime, appropriate management and nutritional strategies during the close up part of the transition period are vital to establish normal macromineral concentrations at parturition.

In the present study, no genetic correlations among serum $\mathrm{Ca}, \mathrm{P}, \mathrm{Mg}$, and $\mathrm{K}$ concentrations and their changes from d 1 to 4 and 1 to 8 after calving were detected. If no genetic correlations exist, this probably denotes no competitive mechanisms at the genetic level that regulate the concentrations of macrominerals; further research is needed to clarify this issue.

Although small, significant positive phenotypic correlations were found between $\mathrm{Ca}$ and $\mathrm{P}$ as well as $\mathrm{Ca}$ and K. These correlations are not easy to explain; for example, one might expect that the action of PTH would result in a negative correlation between $\mathrm{Ca}$ and P. However, at the onset of lactation, large amounts of macrominerals are excreted in the milk which are maintained almost constant, regardless of serum concentrations in the dam, so that adequate mineral supply can be offered to the newborn calf (Grünberg, 2014). This could explain the observed positive phenotypic correlations; moreover, the role of calcitonin in decreasing $\mathrm{Ca}$ and P blood concentration is well established (Allen and Sansom, 1985; Goff, 2000). Calcitonin actually counteracts PTH and, thus, it protects skeleton against major Ca losses during periods of intense Ca mobilization, such as pregnancy and, especially, lactation. It is likely that this might also explain the phenotypic correlation observed in the current study.

An interesting finding was the negative phenotypic correlations of $\mathrm{P}$ with $\mathrm{Mg}$. In humans, the presence of $\mathrm{Mg}$ ions in the binding regions of adenylate cyclase and phospholipase $\mathrm{C}-2$ intracellular molecules that are activated after the binding of PTH to its cell receptorsis essential for the full activation of these 2 secondary messengers and the manifestation of PTH action on target tissues (Rude, 1998; Potts and Gardella, 2007). Therefore, hypomagnesemia reduces the secretion of PTH and decreases the sensitivity of tissues to PTH (Littledike et al., 1983; Goff, 2014). Consequently, this PTH reduction could contribute toward increasing serum P concentration. Moreover, in humans, PTH action in distal tubules reduces $\mathrm{Mg}$ renal excretion and contributes toward increased serum $\mathrm{Mg}$ levels, while at the same time decreases P concentration (Rude, 1998; Swaminathan, 2003). It remains uncertain whether these mechanisms apply to dairy cows as well.

Other interesting findings included the high negative correlations of $\mathrm{Ca}, \mathrm{P}, \mathrm{Mg}$, and $\mathrm{K}$ concentrations on $\mathrm{d} 1$ with the respective changes between $\mathrm{d} 1$ and 4 as well as 1 and 8 . This indicates that the higher the serum concentration on $\mathrm{d} 1$ the smaller is the expected change during the following days (always within normal rage). This seems to be particularly interesting especially for Ca. These observations imply that Ca homeostasis was effective at a population level and support the need for proper nutritional and management strategies during the transition period. Correlations between Ca serum concentration on $\mathrm{d} 1$ and $\mathrm{P}$ serum changes corroborate the previous assumptions. Correlations between $\mathrm{P}$ se- 
rum concentration on $\mathrm{d} 1$ and Ca serum changes follows the same pattern: high concentrations of $\mathrm{P}$ in plasma, at levels greater than $6.0 \mathrm{mg} / \mathrm{dL}$, inhibit the action of renal 1a-hydroxylase $25-(\mathrm{OH})-\mathrm{D}_{3}$, decreasing Ca reabsorption and thus limiting serum Ca concentration increase (Goff, 2014).

Phenotypic correlations between $\mathrm{Mg}$ serum concentration on $\mathrm{d} 1$ and $\mathrm{Ca}$ changes from $\mathrm{d} 1$ to 8 and $\mathrm{P}$ changes from d 1 to 4 and 1 to 8 , as well as $\mathrm{K}$ serum concentrations at $\mathrm{d} 1$ and $\mathrm{P}$ changes from $\mathrm{d} 1$ to 4 and 1 to 8 are difficult to interpret, as they usually remain within normal ranges. Cluster analysis may be the appropriate statistical method to analyze these phenomena.

\section{CONCLUSIONS}

In the present study, significant genetic variation was found in serum macromineral concentrations immediately after calving. During the first $8 \mathrm{~d}$ postpartum, day-to-day heritabilities of serum $\mathrm{Ca}, \mathrm{P}$, and $\mathrm{Mg}$ concentrations traits were moderate to high, whereas those of $\mathrm{K}$ were low to moderate. Genetic evaluation of dairy cows for these traits seems possible and this would contribute to the selection of animals that are less prone to macromineral-related deficiencies during the early stages of lactation that can compromise health and productivity. As these results are the first of their kind, independent validation on different cattle populations would be desirable. Further studies should also focus on the identification of specific genomic regions affecting these traits.

\section{REFERENCES}

Abdel-Azim, G. A., A. E. Freeman, M. E. Kehrli, S. C. Kelm, J. L. Burton, A. L. Kuck, and S. Schnell. 2005. Genetic basis and risk factors for infectious and noninfectious diseases in US Holsteins. I. Estimation of genetic parameters for single diseases and general health. J. Dairy Sci. 88:1199-1207. http://dx.doi.org/10.3168/jds. S0022-0302(05) 72786-7.

Allen, W. M., and B. F. Sansom. 1985. Milk fever and calcium metabolism. J. Vet. Pharmacol. Ther. 8:19-29.

Asagiri, M., and H. Takayanagi. 2007. The molecular understanding of osteoclast differentiation. Bone 40:251-264. http://dx.doi. org/10.1016/j.bone.2006.09.023.

Banos, G., S. Brotherstone, and M. P. Coffey. 2005. Genetic profile of total body energy content of Holstein cows in the first three lactations. J. Dairy Sci. 88:2616-2623. http://dx.doi.org/10.3168/jds. S0022-0302(05)72938-6.

Bastin, C., N. Gengler, and H. Soyeurt. 2011. Phenotypic and genetic variability of production traits and milk fatty acid contents across days in milk for Walloon Holstein first-parity cows. J. Dairy Sci. 94:4152-4163. http://dx.doi.org/10.3168/jds.2010-4108.

Berry, D. P., F. Buckley, P. Dillon, R. D. Evans, M. Rath, and R. F. Veerkamp. 2003. Genetic relationships among body condition score, body weight, milk yield, and fertility in dairy cows. J. Dairy Sci. 86:2193-2204. http://dx.doi.org/10.3168/jds.S00220302(03)73809-0.
Bethard, G., R. Verbeck, and J. F. Smith. 1998. Technical Report 31Controlling Milk Fever and Hypocalcemia in Dairy Cattle: Use of Dietary Cation-Anion Difference (DCAD) in Formulating Dry Cow Rations. 1-5. College of Agricultural, Consumer and Environmental Sciences, New Mexico State University, Las Cruces (http:// aces.nmsu.edu/pubs/research/dairy/TR31/welcome.html).

Cappariello, A., A. Maurizi, V. Veeriah, and A. Teti. 2014. The great beauty of the osteoclast. Arch. Biochem. Biophys. 558:70-78. http://dx.doi.org/10.1016/j.abb.2014.06.017.

Castillo-Juarez, H., P. A. Oltenacu, R. W. Blake, C. E. Mcculloch, and E. G. Cienfuegos-Rivas. 2000. Effect of herd environment on the genetic and phenotypic relationships among milk yield, conception rate, and somatic cell score in Holstein cattle. J. Dairy Sci. 83:807814. http://dx.doi.org/10.3168/jds.S0022-0302(00)74943-5.

Correa, M. T., C. R. Curtis, H. N. Erb, J. M. Scarlett, and R. D. Smith. 1990. An ecological analysis of risk factors for postpartum disorders of Holstein-Friesian cows from thirty-two New York farms. J. Dairy Sci. 73:1515-1524. http://dx.doi.org/10.3168/jds. S0022-0302(90)78819-4.

Daly, J. A., and G. Ertingshausen. 1972. Direct method for determining inorganic phosphate in serum with the "CentrifiChem.". Clin. Chem. 18:263-265.

DeGaris, P. J., and I. J. Lean. 2008. Milk fever in dairy cows: A review of pathophysiology and control principles. Vet. J. 176:58-69. http://dx.doi.org/10.1016/j.tvjl.2007.12.029.

Dyrendahl, I., B. Henricson, and G. Jönsson. 1972. Clinical puerperal paresis and hypocalcaemia in cattle. A statistical and genetic investigation. Zentralbl. Veterinarmed. A 19:621-638.

Gilmour, A. R., B. J. Gogel, B. R. Cullis, and R. Thompson. 2006. ASReml User Guide Release 2.0 VSN International Ltd., Hemel Hempstead, UK. http://www.vsni.co.uk/.

Goff, J. P. 2000. Pathophysiology of calcium and phosphorus disorders. Vet. Clin. North Am. Food Anim. Pract. 16:319-337.

Goff, J. P. 2008. The monitoring, prevention, and treatment of milk fever and subclinical hypocalcemia in dairy cows. Vet. J. 176:50-57. http://dx.doi.org/10.1016/j.tvjl.2007.12.020.

Goff, J. P. 2014. Calcium and magnesium disorders. Vet. Clin. North Am. Food Anim. Pract. 30:359-381. http://dx.doi.org/10.1016/j. cvfa.2014.04.003.

Goff, J. P., and R. L. Horst. 1997. Physiological changes at parturition and their relationship to metabolic disorders. J. Dairy Sci. 80:12601268. http://dx.doi.org/10.3168/jds.S0022-0302(97)76055-7.

Gröhn, Y. T., and M. L. Bruss. 1990. Effect of diseases, production, and season on traumatic reticuloperitonitis and ruminal acidosis in dairy cattle. J. Dairy Sci. 73:2355-2363. http://dx.doi. org/10.3168/jds.S0022-0302(90)78918-7.

Grünberg, W. 2014. Treatment of phosphorus balance disorders. Vet. Clin. North Am. Food Anim. Pract. 30:383-408. http://dx.doi. org/10.1016/j.cvfa.2014.03.002.

Heringstad, B., Y. M. Chang, D. Gianola, and G. Klemetsdal. 2005. Genetic analysis of clinical mastitis, milk fever, ketosis, and retained placenta in three lactations of Norwegian red cows. J. Dairy Sci. 88:3273-3281. http://dx.doi.org/10.3168/jds.S00220302(05)73010-1.

Kadarmideen, H.N., R. Thompson, G. Simm, and M. Eh. 2000. Linear and threshold model genetic parameters for disease, fertility and milk production in dairy cattle. Anim. Sci. 71:411-419.

Kaneko, J. J., J. W. Harvey, and M. L. Bruss. 2008. Thyroid function. Pages 623-634 in Clinical Biochemistry of Domestic Animals. Academic Press, Cambridge, UK.

Kronqvist, C. 2011. Minerals to dairy cows with focus on calcium and magnesium balance. Doctoral Thesis. Sveriges lantbruksuniv., Acta Universitatis agriculturae Sueciae, Uppsala, Sweden.

Lean, I. J., R. Van Saun, and P. J. Degaris. 2013. Energy and protein nutrition management of transition dairy cows. Vet. Clin. North Am. Food Anim. Pract. 29:337-366. http://dx.doi.org/10.1016/j. cvfa.2013.03.005.

Lin, H. K., P. A. Oltenacu, L. D. Van Vleck, H. N. Erb, and R. D. Smith. 1989. Heritabilities of and genetic correlations among six health problems in Holstein cows. J. Dairy Sci. 72:180-186. http:// dx.doi.org/10.3168/jds.S0022-0302(89)79095-0. 
Littledike, E. T., and J. Goff. 1987. Interactions of calcium, phosphorus, magnesium and vitamin $\mathrm{D}$ that influence their status in domestic meat animals. J. Anim. Sci. 65:1727-1743.

Littledike, E. T., J. A. Stuedemann, S. R. Wilkinson, and R. L. Horst. 1983. Grass tetany syndrome. Page 173 in Proc. John Lee Pratt Int. Symp. Role Magnes. Anim. Nutr. Virginia Polytechnic Institute and State University, Blacksburg, VA.

Lyons, D. T., A. E. Freeman, and A. L. Kuck. 1991. Genetics of health traits in Holstein cattle. J. Dairy Sci. 74:1092-1100. http://dx.doi. org/10.3168/jds.S0022-0302(91)78260-X.

Martinez, N., L. D. P. Sinedino, R. S. Bisinotto, E. S. Ribeiro, G. C. Gomes, F. S. Lima, L. F. Greco, C. A. Risco, K. N. Galvão, D. Taylor-Rodriguez, J. P. Driver, W. W. Thatcher, and J. E. P. Santos. 2014. Effect of induced subclinical hypocalcemia on physiological responses and neutrophil function in dairy cows. J. Dairy Sci. 97:874-887. http://dx.doi.org/10.3168/jds.2013-7408.

NRC. 2001. Nutrient Requirements of Dairy Cattle. 7 th rev. ed. Natl. Acad. Press, Washington, DC.

Oetzel, G. R. 2011. Diseases of dairy animals-Non-infectious diseases: Milk fever. Pages 239-245 in Encyclopedia of Dairy Sciences. 2nd ed. J. W. Fuquay, ed. Academic Press, San Diego, CA.

Oikonomou, G., G. E. Valergakis, G. Arsenos, N. Roubies, and G. Banos. 2008. Genetic profile of body energy and blood metabolic traits across lactation in primiparous Holstein cows. J. Dairy Sci. 91:2814-2822. http://dx.doi.org/10.3168/jds.2007-0965.

Peek, S. F., and T. J. Divers. 2008. Metabolic diseases. Pages 590-605 in Rebhun's Diseases of Dairy Cattle. 2nd ed. T. J. D. F. Peek, ed. W.B. Saunders, St. Louis, MO.

Potts, J. T., and T. J. Gardella. 2007. Progress, paradox, and potential: Parathyroid hormone research over five decades. Ann. N. Y. Acad. Sci. 1117:196-208. http://dx.doi.org/10.1196/annals.1402.088.

Pradhan, K., and R. W. Hemken. 1968. Potassium depletion in lactating dairy cows. J. Dairy Sci. 51:1377-1381. http://dx.doi org/10.3168/jds.S0022-0302(68)87198-X.

Pryce, J. E., R. F. Veerkamp, R. Thompson, W. G. Hill, and G. Simm. 1997. Genetic aspects of common health disorders and measures of fertility in Holstein Friesian dairy cattle. Anim. Sci. 65:353-360. http://dx.doi.org/10.1017/S1357729800008559.

Rajala-Schultz, P. J., Y. T. Gröhn, and C. E. McCulloch. 1999. Effects of milk fever, ketosis, and lameness on milk yield in dairy cows. J. Dairy Sci. 82:288-294. http://dx.doi.org/10.3168/jds.S00220302(99) $75235-5$.
Reinhardt, T. A., J. D. Lippolis, B. J. McCluskey, J. P. Goff, and R. L. Horst. 2011. Prevalence of subclinical hypocalcemia in dairy herds. Vet. J. 188:122-124. http://dx.doi.org/10.1016/j.tvjl.2010.03.025.

Rérat, M., A. Philipp, H. D. Hess, and A. Liesegang. 2009. Effect of different potassium levels in hay on acid-base status and mineral balance in periparturient dairy cows. J. Dairy Sci. 92:6123-6133. http://dx.doi.org/10.3168/jds.2009-2449.

Rude, R. K. 1998. Magnesium deficiency: A cause of heterogeneous disease in humans. J. Bone Miner. Res. 13:749-758. http://dx.doi. org/10.1359/jbmr.1998.13.4.749.

Sattler, N., and G. Fecteau. 2014. Hypokalemia syndrome in cattle Vet. Clin. North Am. Food Anim. Pract. 30:351-357. http:// dx.doi.org/10.1016/j.cvfa.2014.04.004.

Sattler, N., G. Fecteau, C. Girard, and Y. Couture. 1998. Description of 14 cases of bovine hypokalaemia syndrome. Vet. Rec. 143:503507. http://dx.doi.org/10.1136/vr.143.18.503.

Swaminathan, R. 2000. Magnesium metabolism and its disorders Clin. Biochem. Rev. 24:47-66.

Tauriainen, S., S. Sankari, S. Pyörälä, and L. Syrjälä-Qvist. 2003. Effect of anionic salts on some blood and urine minerals, acid-base balance and udder oedema of dry pregnant cows. Agric. Food Sci Finl. 12:83-93.

Tveit, B., M. Svendsen, and K. Hove. 1991. Heritability of hypocalcemia at first parturition in Norwegian cattle: genetic correlations with yield and weight. J. Dairy Sci. 74:3561-3567. http://dx.doi. org/10.3168/jds.S0022-0302(91)78548-2.

Uribe, H. A., B. W. Kennedy, S. W. Martin, and D. F. Kelton. 1995. Genetic parameters for common health disorders of Holstein cows. J. Dairy Sci. 78:421-430. http://dx.doi.org/10.3168/jds.S00220302(95) 76651-6.

Van Dorp, T. E., J. C. Dekkers, S. W. Martin, and J. P. Noordhuizen. 1998. Genetic parameters of health disorders, and relationships with 305-day milk yield and conformation traits of registered Holstein cows. J. Dairy Sci. 81:2264-2270. http://dx.doi.org/10.3168/ jds.S0022-0302(98)75806-0.

Windig, J. J., M. P. L. Calus, B. Beerda, and R. F. Veerkamp. 2006. Genetic correlations between milk production and health and fertility depending on herd environment. J. Dairy Sci. 89:1765-1775. http://dx.doi.org/10.3168/jds.S0022-0302(06)72245-7. 